\title{
THE WAY PUBLIC RELATIONS PRACTITIONERS INFLUENCE MEDIA AGENDAS IN VIETNAM
}

\author{
Van Thi Hong Loan \\ Ho Chi Minh City Open University \\ Email: loan.vth@ou.edu.vn
}

(Received: 05/04/2015; Revised:06/08/2015; Accepted: 14/08/2015)

\begin{abstract}
The paper provides empirical evidence for the development of the theory of media agendasetting. The power of the media, according to the theory, has been changed in public relations in Vietnam. Public relations practitioners have power to shape media content as they desire. This research uncovers that public relations practitioners not only impact media agendas as the theory describes, but also do the job of journalists. While public relations practitioners in the West use framing and information subsidies to influence media agendas for the public, this study indicated that practitioners in Vietnam tend to be responsible for public relations editorials that are considered as the main duty of media people. The paper additionally explains the way Vietnamese journalists conduct news to underpin understanding of the characteristics of media relations in the country. This paper also presents a Tripolar model of corporate, media and public agendas which was designed based on the research data.
\end{abstract}

Keywords: Agenda-setting, Framing, Media agendas, Information subsidies, Public relations.

\section{Introduction}

The agenda-setting theory is about the mass media effects on the public of news items being chosen for significant media, while other items are either not published or given less importance. McCombs \& Shaw's (1972) research found that the media is a powerful force in shaping what and how the public think about the significant issues of the day. An agenda is a set of current issues and events which have priority at a particular time. Agenda-setting influences cognition (awareness) of the public such as thinking, knowing, remembering, judging and problemsolving. In other words, the opinions, attitudes and behavior of the public can be changed by media agendas. But who sets agendas for the media? Who influences the process of agendasetting? Some researchers said that public relations $(\mathrm{PR})$ practitioners can influence the media agenda-setting in a country where PR is conducted. Members of the news media (e.g. editors) are gatekeepers that set public issues agendas through their choice and editing of news. The media choose PR information (provided by PR practitioners) based on the value of its news, and this agenda-setting influences audiences. In the West, PR people do not have the right to set media agendas. PR people can influence media agendas through providing information to journalists. Zoch \& Molleda (2006) guessed that PR practitioners and media people can work together to shape media agendas. However, these scholars had not yet known how they collaborate. Whether PR practitioners set media agendas is still no evidence in world literature. So, this research will explore this issue in Vietnam-whether 
Vietnamese PR practitioners do the job of journalists-set media agendas. This study hopes to provide evidence about the power of PR people in Vietnam. The media environment, which is considered as the field of the media, may also shape by PR people.

This study thus aims to explore whether and how PR practitioners and journalists in Vietnam collaborate to impact media agendas. In other words, the research will study whether and how PR practitioners participate in the process of media-setting. In addition, the study aims to explore whether and how PR practitioners set media agendas - means that PR practitioners not only influence but also themselves set agendas for the media this inquiry has not yet shown in literature. The study also aims to develop a model of PR agendas in which presents their influence on media agendas. Specifically, the study will answer three main questions as follows:

(1) Whether and how do PR practitioners and journalists collaborate to influence media agendas?

(2) Whether and how do public relations professionals themselves set media agendas?

(3) Do public relations agendas influence media agendas? If yes, which model is suggested?

\section{Literature review}

Who sets media agendas?

This issue was considered in some earlier research by Cobb \& Elder (1972), and Lang \& Lang (1981). While Cobb \& Elder (1972) argued that there is influence of political leaders on media agendas, Lang \& Lang explained that agenda-setting is a process which politicians can view their images through the public's opinion (Lang \& Lang, 1981). Agenda-setting 'is a collective and reciprocal process' (Zoch \& Molleda, 2006, p. 287), as the deliverers and the receivers of messages have an impact on each other. This process also means there are mutual influences within the media, the public and politicians (Johnson et al., 1996; Zoch\&Molleda, 2006). The media set agendas and PR professionals can influence agendas for the media. There is a reciprocal relationship between the media and PR professionals.

Some scholars (McCombs, 1992; Roberts \& McCombs, 1994) posited that the sources of information set agendas for the media. McCombs (2005) specifically explained that sources of the media agenda are from media officials themselves, resulting from communication between news organisations and other sources. Journalists evaluate the value of news based on looking for 'the work of their colleagues' in particular that of 'elite members of the press' (McCombs, 2005, pp. 548-549), indicating that leading journalists play a critical role.

PR practitioners are one of the outside sources of the media, and they provide information for the media, and the media use the information, because it has news value (Cutlip et al., 2006). The issue here is that if journalists fail to validate information from an outside source, do they receive information without argument, such as no editing in terms of a government's material (Stanton, 2009), because they trust the outside source, or are controlled by the government? This can be an important difference between the media in Eastern and Western countries, as 'in the West the news media represent themselves as independent and objective' (Stanton, 2009, p. 366). Who sets agendas for the media in this case in Vietnam? Related to this question, Weaver \& Elliot (1985, p. 87) stated that 'it is not quite accurate to speak of the press setting agendas if it is mainly passing on priorities set by other actors...in the society'.

'Other actors' can be public officials, policy actors, politicians and public relations practitioners through providing information which has news value to the media (Cobb \& Elder, 1972; Johnson et al. 1996). By 
distributing newsworthy information for the press, public relations practitioners can participate in the process of media agendasetting. Public relations practitioners purposely choose new and important PR information and stories to send to the media from whom they can be published. In brief, public agendas can be influenced by several different groups such as the news organisations (the media), political officials (governments) and PR practitioners (organisations). This issue was demonstrated in a study by Watson (2008) as he found that there are four agendas: public agenda, policy agenda, media agenda and corporate agenda in which the central public agenda is influenced by the three factors (p. 154; see also Figure 1). While a public agenda is a set of items to be discussed in the media have an impact over the way the public think, a policy agenda is a list of problems and subjects to which people inside government (e.g. government officials and government decision-makers) and outside government paying serious attention a particular time. Media agendas are usually set by journalists whereas corporate agendas are set by people in a company. Corporate agenda is things that organization considers to be important and wants to solve or achieve. These agendas are related and influenced by each other. Public relations practitioners (corporate agenda) can influence public agendas through media relations. My research focuses on how public relations practitioners in Vietnam influence media agendas, however, policy agendas are not emphasised in my study due to the scope of the research

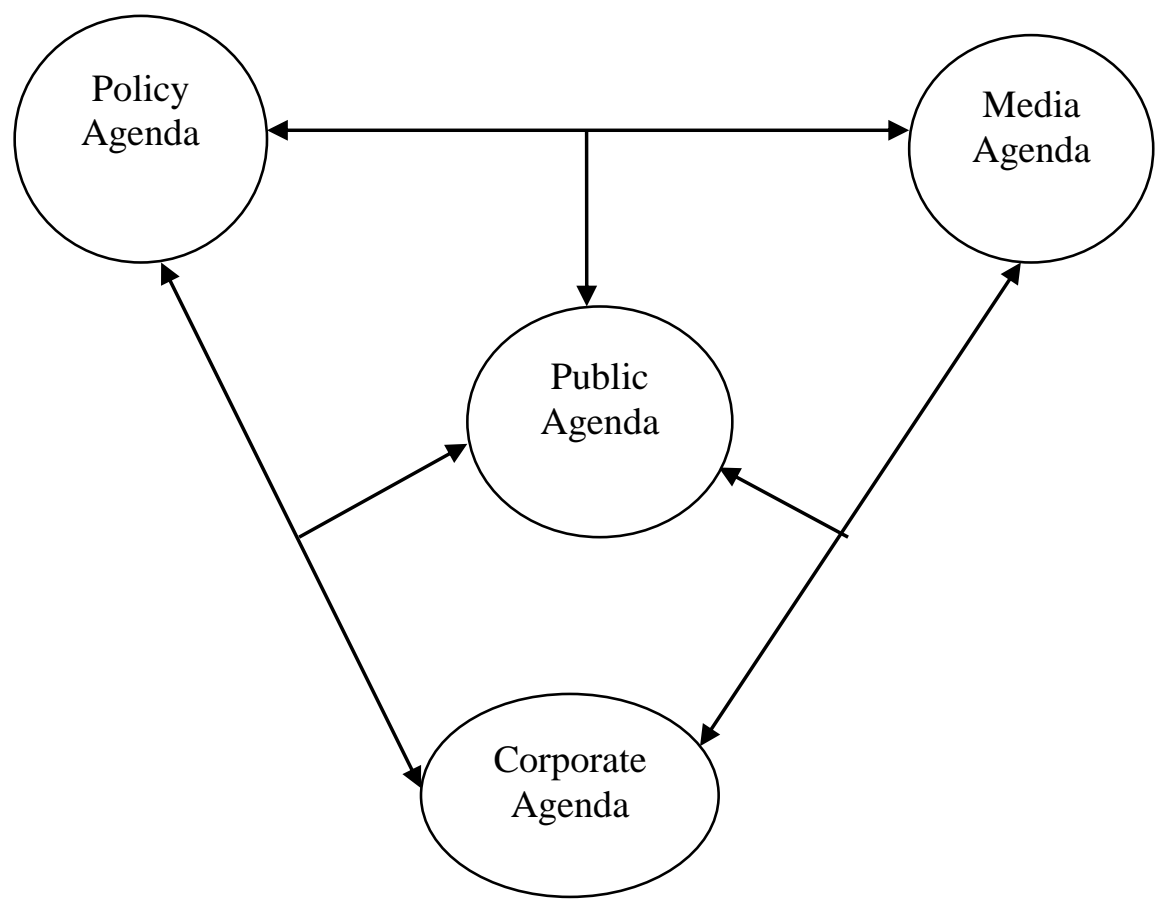

Figure 1. Tripolar model of agendas: policy, corporate and media (Source: Watson, 2008, p. 154)

It can be seen that people who participate in the process of media agendasetting are not only the media but also public relations practitioners who are in collaboration with the media.
How public relations practitioners set media agendas?

PR practitioners can influence media agendas, and 'framing' and 'information subsidies' are two tools PR practitioners can 
use to contribute to this process (Zoch \& Molleda, 2006, p. 290). Framing is a form of agenda-setting. A media frame is 'the central organizing idea for news content that supplies a context and suggests what the issue is through the use of selection, emphasis, exclusion and elaboration' (Tankard et al. 1991, p. 3, cited in McCombs \& Ghanem, 2001, p. 70). The concept of 'framing' was first mentioned by anthropologist Bateson (1955) about a 'frame' of interpretation or meta-message in a specific situation. While Goffman (1974), one of the first scholars to study 'framing', defined a 'frame' as a 'schemata of interpretation' through which practitioners organise and make sense of information (p. 21), Reese (1997) described that 'frames are organizing principles that are socially shared and persistent over time, that work symbolically to meaningfully structure the social world' (p. 5). Goffman (1974) also talked about 'social frames' which 'provide background understanding for events that incorporate the will, aim, and controlling effort of an intelligence [and] a live agency' (p. 22). It can be seen that framing can be used to construct or form the 'social world' or the way people view social reality. So, framing can be used as a tool to shape social reality or, more specifically, in media and public relations field, to set agendas. In public relations, framing is used to organise and package information, and PR practitioners aim to 'frame an issue or event' that meets 'the existing or known frames of reference used by the media' (Stanton, 2007, p. 19). While Goffman (1974) attempted to link the 'social frame' with social reality, my study will try to make sense of it within the Vietnamese society in terms of the public relations role and how it frames public agendas.

After comprehensive reviews of literature about 'framing', Hallahan (1999) recognised the relationship between 'framing' and public relations, and stipulated that 'framing plays an integral role in public relations' (p. 207). Framing helps practitioners to define, identify, judge and treat problems (Entman, 1993; Zoch \& Molleda, 2006). In the process of media agenda-building, PR practitioners use framing through choosing information, highlighting it, organising it and transferring it to the media (Harrison, 2011). How public relations practitioners in Vietnam use 'framing' to influence media agendas is a consideration of my study, as they may frame their messages through their cultural lens, or in line with the political environment.

Information subsidies are another tool that public relations practitioners use to build media agendas, as they 'generate prepackaged information to promote their organisations' viewpoints on issues' to their stakeholders (Zoch\&Molleda, 2006, p. 284). Gandy (1982) derived this concept and described 'information subsidies' or the 'packaged information' which are generated by public relations practitioners as 'efforts to reduce the prices faced by others for certain information in order to increase its consumption' (p. 8). Public relations practitioners use information subsidies, or the generation of information to 'facilitate the newsgathering process' of news organisations, as they generate news releases (Newsom et al., 2000, p. 238). This process brings benefits to both the organisation of practitioners and news organisations (Zoch\&Molleda, 2006). Practitioners themselves collect information, select it, elaborate it and disseminate it (e.g. news releases) to the press. This saves time and effort for journalists (Harrison, 2011), and in some cases, public relations professionals can write PR articles. This means there must be a compromise between journalists and PR professionals in terms of setting agendas for the public.

For journalists and editors' use, Gandy (1982) pointed out that they use a news 
release depending on its news value and quality. The value of the news release increases if editors or reporters understand and have a good relationship with the author of the news release (Kopenhaver, 1985). Some research also found that the process of setting media agendas has greater impact if an outside source of information (i.e. public relations practitioners) builds good personal relationships with the media, such as journalists, reporters, and editors (Berkowitz \& Adams, 1990; Lipschultz, 1991; Cameron et al., 1997). Personal relationships are also important in media relations in Western countries, but the way they are managed in Asian countries may be different to that in Western countries. Personal relationships in Asian countries reflect the national culture, and their features such as face and favour are cultural characteristics of some Asian cultures (e.g. China, Taiwan, and Vietnam) which are widely used in society, including in private life and business (see, e.g. Sriramesh et al., 1999; Berkowitz \& Lee, 2004; Huang, 2000; Chen \& Culbertson, 2009; Chen, 1996). Scholars such as Berkowitz \& Adams (1990) assert that in order to effectively influence local television news in terms of public relations, public relations practitioners should both create news events, and develop interpersonal relationships with reporters (the media). But how is the relationship developed? This inquiry is still on-going in public relations research. There is a need to understand how public relations and news media work together to shape public agendas (Zoch\&Molleda, 2006; Cameron et al., 1997). My study will explore how public relations practitioners and journalists collaborate to impact public agendas, and what that means to public relations practice.

\section{Research methods}

In-depth interviews

Twenty-nine consultants and in-house public relations practitioners were interviewed from 60 to 90 minutes. These were twenty-six Vietnamese nationals and three internationals. Consultants included consultants, senior consultants and chief executive officers (CEOs). The CEOs were senior and leading consultants who were managing and directing public relations in the consultancies. The three international CEOs had experiences in public relations in Vietnam and in other countries. Two of them had worked in public relations in different Asian countries such as Thailand, Singapore and Malaysia. In this study, the researcher interviewed eight CEOs of the eight consultancies. All the Vietnamese CEOs had worked in the field for both international and domestic sectors in Vietnam. They had worked in marketing and communications departments in multinational corporations whose offices were in Vietnam (e.g. Coca Cola Beverages Vietnam Limited and Unilever Vietnam). After gaining public relations experience from these corporations, they themselves set up their business as public relations consultancies. With the young history of public relations in Vietnam, this sample was significant for the research because it provided very important and valuable data related to the overall professional picture of public relations in this country. In-house public relations practitioners chosen for the study were working for public relations departments in the international and Vietnamese business companies. They worked for public relations departments, and were responsible for public relations activities and programs in their organisations. In this research, all of them were Vietnamese nationals. The findings, which the researcher collected, presented and discussed below, indicate that the researcher chose the right sample.

\section{Informal document reviews}

The reliability of the data is enhanced by using supplementary sources to support an understanding of the interview data. This 
study utilised additional documents to make sense of the interviews. These were:

- The public relations experts' interviews by journalists were published on newspapers, or speeches by public relations consultants in conferences about public relations in Vietnam from 2010 to 2014 were used for understanding the primary data. These were discussions about the current practice of public relations and the reasons for the cooperation between local public relations consultancies and multinational ones. Most of the articles chosen were based on the criterion related to interviewees as public relations professionals. For example, the interviewees have to be specialists in the field in Vietnam, in other words, they worked for the field, studied about it and had experience of public relations in Vietnam.

- The researcher also reviewed empirical research of public relations in Vietnam such as those by McKinney (2007), Nguyễn Thị Thanh Huyền (2010) and Van Thi Hong Loan (2014) to support an understanding of my data. Research by Van Thi Hong Loan (2014) talked about the use of personal relationships by PR practitioners to influence agendas which designed by Vietnamese journalists. However, she had not linked this issue to the theory of media agendas; and had not analysed the differences between public relations in Vietnam and the West in terms of agenda-setting. Although there is little empirical research, the review helps to recognise a difference and similarity between my research and their research.

\section{Data analysis}

Each interview was transcribed from the digital recorder after completing the interview. Each interviewee was given a pseudonym and all of his/her responses in a file under this pseudonym. In the process of the data collection, the researcher recognised the differences amongst research participants so there was a different description for each category. There were differences between chief executive officers (CEOs) and consultants, between consultants and in-house public relations practitioners, and between Vietnamese people and people from other countries. The pseudonyms thus were given as follows: VCC1-VCC5: Vietnamese Consultants and CEOs; VC1-VC14: Vietnamese Consultants; VI1-VI7: Vietnamese In-house public relations practitioners; OCC1-OCC3: Consultants and CEOs from Other countries.

Coding was used in this study after the data collection as the systematic labelling of concepts to allow for easy retrieval of data across the data set. The different ideas were named with the different labels and the similar ideas were grouped into the same label. The data from the interview transcripts were analysed, noted, grouped and labelled as categories. In this research, data coding was conducted from the ideas and viewpoints of the study participants, based on their responses. The researcher used qualitative data analysis software Nvivo version 8.0 which is an information management software package designed for use in qualitative research. This software assisted the analysis of the data because it is supported to electronically archive, and organise categories into hierarchies for easy approach, re-visiting, and re-examination of the data. A gap in the current theory of media agenda-setting was identified after an intensive process of coding, classifying and weighing, comparing and contrasting, and interpret the data. 


\section{Results}

Almost all respondents said that in current practice, public relations mostly focuses on media relations (i.e. sending relevant information to the media), media coverage (i.e. publishing public relations articles on newspapers) and public relations events (i.e. arranging press conferences). Commenting on activities of public relations in Vietnam at the present, an American participant stated that Vietnamese public relations always likes to set up news conferences. This means that practitioners in Vietnam like to create new information or events for public relations. He said:

The style of PR in Vietnam is lot of coverage... As I worked in the United States for five to six years, I only did one conference. But in Vietnam, press conferences are conducted all the time.

Media relations, media coverage and public relations events are prominent in public relations in Vietnam. The respondents stressed that they always contact media people to deliver their information including events of public relations. They also noted that they want their messages to appear on editorials which are under the imprimatur of the editors rather than on advertorials. They thought that customers trust their messages on editorials more than advertorials. Vietnamese customers may trust what journalists write (editorials) rather than what practitioners write (e.g. advertorials). In Vietnam, advertorials are often created by PR professionals and published on the section of the advertisement of a newspaper.

It is not easy to put their messages on editorials because of the official permission required by newspaper editors. PR practitioners thus tend to influence journalists to put their messages on editorials. Building the trust between them and journalists through setting up personal relationships is one of the important ways they use. Here findings focus on the way they influence media agendas through providing their public relations information. In other words, PR practitioners influence media agendas through using tools such as framing and information subsidies (Zoch \& Molleda, 2006). That means practitioners choose information, highlight it, organise it and transfer it to the media. They also generate their public relations information into news releases and advertorials to promote their products and organisation. Their aims are to reduce public relations cost, to save time and efforts for journalists but they may also mislead their publics. The interesting issue in the research is that practitioners affect media agendas not only through information subsidies they provide to the media such as news releases and advertorials, but also through editorials where they provide information to the media, or they create editorials for journalists. PR professionals influence the process of media agenda-setting by themselves creating public relations editorials which are considered the main duty of journalists. A managing director in the research explained why his consultancy prepares editorials and why international practitioners cannot understand this. That is because there is a difference in conducting news by journalists in Vietnam and other countries, especially the Anglo countries. Practitioners in other countries may not write public relations editorials for journalists to promote their products and organisation. He said:

We want to put our messages on newspapers. We like to make it easy for journalists because they have many deadlines and so many editorials need to be submitted. We do it for them. International people cannot understand this because they think it is the duty of journalists.

The main priority of the media is to disseminate the government's policies. The accuracy of information in producing news is 
thus not the first priority of Vietnamese newspapers. As a consequence, the competitiveness of gaining exclusive information in the media is not critical. Journalists in one newspaper can share information which they have with other journalists in other newspapers.

Vietnamese journalists do not tend to crosscheck information public relations practitioners provide to produce news if they have good personal relationships. They tend to share their information with other journalists even journalists in other news agencies in terms of conducting news into editorials. A consultant said:

There is no exclusive article and information in newspapers. Journalists can share information with others to conduct editorials.

Another consultant agreed with this issue:

We have to be responsible for information we provide. Journalists often do not check the accuracy of the information.

After the data analysis, the researcher identified three tactics which the respondents use to influence the process of media agendasetting in terms of editorials. Firstly, public relations people provide relevant information for journalists. Based on the personal relationships between practitioners and journalists which were previously established, journalists tend to put the messages practitioners provide on their editorials. As the public relations editorials are published, journalists inform the practitioners. The practitioners usually use coffee, meals and gifts to thanks the journalists. The second way is similar to the first way. That means journalists put public relations messages on their editorials. The difference is that practitioners pay for journalists, or media agents according to the compromise, or negotiation between them and the practitioners. Many newspaper offices in Vietnam tend to use this activity as part of their business. Public relations in this case looks like a kind of promotion or advertising. Thirdly, professionals themselves, in a few organisations prepare public relations editorials and then transfer them to journalists. There is a compromise between them and journalists (see Table 1).

Table 1. Three tactics practitioners in Vietnam use to influence media editorials

\begin{tabular}{|c|l|l|}
\hline Category & \multicolumn{1}{|c|}{ Writer } & \multicolumn{1}{|c|}{ Tactics } \\
\hline 1 & Journalists & $\begin{array}{l}\text { PR people provide relevant information for journalists. } \\
\text { Based on personal relationships with journalists, they } \\
\text { usually use coffee, meals and gifts to thank them. }\end{array}$ \\
\hline 2 & Journalists & $\begin{array}{l}\text { PR people provide relevant information for journalists. } \\
\text { They often pay for media agents or journalists. }\end{array}$ \\
\hline 3 & $\begin{array}{l}\text { PR professionals } \\
\text { (journalists usually edit } \\
\text { them). }\end{array}$ & $\begin{array}{l}\text { PR people themselves conduct PR editorials. They use } \\
\text { personal relationships with journalists to put the } \\
\text { editorials on newspapers. They use coffee, meals, gifts } \\
\text { and tips to thank them. }\end{array}$ \\
\hline
\end{tabular}

In Table 1, public relations professionals in international organisations (including consultancies and companies) usually focus on Category 1 because they said that paying for media is not their organisations' policy. However, the managing directors of these organisations have begun to accept using coffee, gifts, or tips for media 
people. In contrast, many Vietnamese organisations tend to use the approach in Category 2. Joint-venture organisations (between international and Vietnamese ones) use both Category 1 and 2 approaches. To Category 3, only few large organisations use it because they have professionals who can create editorials and understand public relations.

The participants also noted that they have to understand the way of the media and the requests of the policy actors to create public relations information and information subsidies such as news releases and advertorials. In other words, practitioners can contribute to the process of media agendasetting if they understand the government policies and the way the Vietnamese media conduct news. Through the in-depth interviews with consultants and in-house people, the research identifies important issues which practitioners need to consider in practice. The first relates to cultural, social and economic conditions in Vietnam. Messages in public relations articles should not shock the public. The government and the media may be afraid of social confusion. A respondent explained:

The topics have to be suitable with Vietnamese culture. For example, they do not cause shocks to audience. As my consultancy did the project related to food safety, we wanted to push the topics which cause extreme shocks to the publics. We wanted to raise the public awareness of this problem deeply. However, journalists did not want us to show such information on the PR articles because they were afraid that small businesses would be impacted (i.e. bankruptcy).

Another consideration which practitioners should be careful of when conducting information subsidies, is that of reporting and writing about sexual issues. A respondent said:

Sexual issues are usual in terms of using it in PR in Western countries but in Vietnam, we are so careful using it, especially putting it in PR articles because it is a sensitive topic in Vietnam and Vietnamese media.

The next consideration which practitioners need to take into account relates to comparison in public relations. PR practitioners need to avoid directly comparing brands, products and companies when creating public relations articles. The respondents noted that comparison is a way they often use in public relations to highlight their products and to lower their competitors' products. However, practitioners are often not allowed to use this approach. A participant stated:

There is an informal agreement between PR people and the media related to PR articles: do not say anything best; do not compare two brands directly; do not speak ill of our competitors, etc. Comparison is a method of PR. However, we have to do it cleverly.

\section{Discussion}

The findings show that although activities regarding media relations, media coverage and public relations events are prominent in public relations in contemporary Vietnam, practitioners seem to want to practice much more than that. They tend to conduct more professional activities and extend current public relations activities. Media relations are still a main function of public relations departments. The findings indicate that practitioners in Vietnam participate in the process of media agendasetting. They use framing and information subsidies such as providing news value, news releases and advertorials to influence this process. Moreover, these are more than tools in setting media agendas in Vietnam. Practitioners use three tactics to influence 
media editorials. In the first and second tactic, through the compromise with journalists, they provide relevant information to journalists to create editorials which highlight their products and organisations. While the first tactic focuses more on the personal relationships with journalists, the second tactic emphasises paying for the media as a way to influence media agendas. Media editorials in the third tactic are impacted by public relations professionals due to the compromise arrangements with journalists. Professionals themselves create editorials in which their public relations messages are controlled as they need. Practitioners in Vietnam recognise that the more they understand the way of the media and maintain the relationships with journalists, the more they influence media agendas. They recognise that they should consider the context of Vietnam including the cultural, social and economic conditions and governmental policies in conducting agendas. The research identifies that the more PR practitioners understand media agenda-setting and develop the connection with journalists, the more they impact media agendas.

In addition, the accuracy of information in producing news is not the first priority of the media. Vietnamese journalists do not tend to crosscheck information $\mathrm{PR}$ practitioners provide to produce news if both of them (journalists and PR practitioners) are in the same network. This means they have good personal relationships and trust each other. International public relations practitioners thus found this strange. If consultants provide incorrect information for journalists, it will be hard for both of them (PR practitioners and journalists) in the long-term. There is an informal agreement and commitment between both of them in their network. However, due to the way public relations is conducted in the Anglo countries, international practitioners consider that journalists must crosscheck information they provide before creating news; that is the duty of journalists. Clearly, the difference in the media environment, and the way news is produced by journalists may lead to difficulties for PR practitioners from Anglo countries, in terms of media relations. This finding supports the stance of other researchers (e.g. Sriramesh \& Verčič, 2009) who suggested that public relations is impacted by contextual factors such as media environment where it is practiced.

The findings show that PR practitioners provide favourable information, and avoid reporting unfavourable information about their products or services for journalists. They select information, highlight it, organise it and then transfer it to news media. They also generate information subsidies, such as news releases and advertorials about their products or organisations, and then send them to the media; much of this has a marketing focus. As PR practitioners want to downplay negative information regarding their faulty products, journalists can help them to put their information subsidies, such as news release in the media. It can be recognised that setting media agendas is the duty of journalists, but PR practitioners also affect media agendas through framing and information subsidies. These findings are consistent with those of other research (e.g. Zoch \& Molleda, 2006; Williams, 2004; Curtin \& Rhodenbaugh, 2001; Curtin, 1999; Turk, 1985) who found that the influence of public relations activities is on media agenda-setting. Practitioners participate in the process of media agendasetting via their activities such as providing PR information and information subsidies for journalists.

However, public relations in Vietnam does much more than that. This means PR practitioners not only influence media agendasetting but also set PR editorials which are considered as the main duty of journalists. The study findings indicate that journalists set 
media editorials according to PR organisations' desire. Through PR information whichpractitioners provide about products or services, journalists create editorials that highlight products or services according to the way practitioners, or their organisations want. In addition, the data suggests that PR professionals themselves create PR editorials that promote their products or services. PR professionals do the job of journalists. The role of PR professionals also includes the role of journalists. That means PR professionals have to think as journalists, have to behave as journalists and have good writing skills. Writing skills (Vietnamese and English) are important, which almost all respondents and their organisations focused on, to recruit PR practitioners. The way public relations in Vietnam conducts PR is subtly different to the way public relations is practiced in Anglo countries. In my literature review, there is little research which focuses on this issue: PR professionals in the role of journalists. The public relations-journalism relationship in the United States, for example, is important but journalists would not be pleased if public relations do their work for them. Nguyễn Thị Thanh Huyền (2010) said that professional relationships between Vietnamese journalists and public relations practitioners are hierarchical relationships, however, the analysis of the findings indicate it is evident that their relationships (journalists and public relations practitioners) are mutual relationships where both of them exchange information, provide consultation, and help each other, and that public relations often dominants the relationships.

The agenda-setting theory talks about the influence of the media on the public and the influence of public relations on media agendas and public agendas. Public relations professionals can participate in the process of media agenda-setting through framing and information subsidies (Zoch \& Molleda, 2006). My literature review shows that in nations such as Malaysia, Singapore and Taiwan, public relations professionals impact media agendas because governments use public relations as a political tool for national building and crisis management (Van Leuven, 1996; Taylor, 2000; Wu et al., 2001). That means public relations professionals, as government officers, may use their power to influence public relations programs in these countries. However, my research findings extend this role, so that PR professionals in Vietnam affect, and set media editorials according to their desire, not by the influence of the government. Even though in Vietnam, the government controls the media and media agendas are controlled by the government, PR professionals have power in terms of impacting public relations editorials as they want. As such they affect the communication to the public about organisations' products and services. Berkowitz \& Adams (1990), Lipschultz (1991) and Cameron et al. (1997) found that the more PR practitioners build good personal relationships with the media, the greater the influence on the process of setting media agendas is, but how the relationships between them developed is still an on-going inquiry in public relations research. In other words, how public relations and the media work together to shape public agendas (Cameron et al., 1997; Zoch \& Molleda, 2006). My research gives some answers to this question. The findings of my research indicate that public relations programs which affect corporate agendas influence not only the way the media set agendas, but also the agendas for the public. It can be recognised that in Vietnam, public relations agendas influence media agendas, corporate agendas and public agendas (see Figure 2). This model (Figure 2) is slightly different to Watson's (2008) model (see Figure 1). While Watson (2008) said that 
public agendas are central, influenced by policy, media and corporate agendas, the model below suggested by the researcher, shows that public relations agendas are central, which influence corporate, media and public agendas.

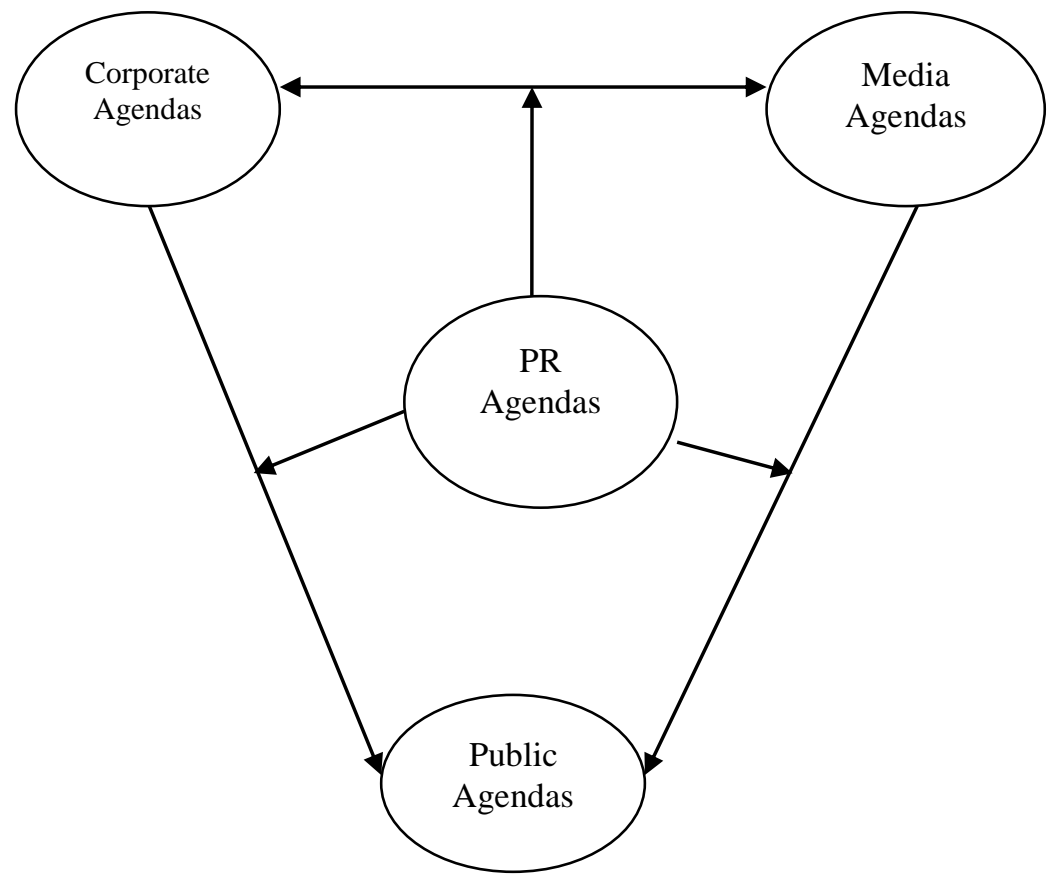

Figure 2. Tripolar model of agendas: corporate, media and public (Van Thi Hong Loan, 2015) (Adapted from Watson's (2008) model)

\section{Conclusion}

This research offered evidence to point that PR practitioners and journalists collaborate to shape media agendas. Through their good personal relationships, journalists allow PR practitioners design PR editorials and then put them on the media. The study has challenged the theory of media agenda- setting as showing the way PR practitioners and journalists work together to influence agendas for the public-the question which is still in progress in world research. The study provided the answer of this inquiry and developed the Tripolar model of agendas in which PR agendas influence corporate agendas, public agendas and media agendas.

\section{REFERENCES}

Bateson, G. (1955). A theory of play and phantasy. Psychiatric Research Reports, 2, 39-51.

Berkowitz, D. \& Adams, D. B. (1990). Information subsidy and agenda-building in local television news. Journalism Quarterly, 67, 723-731.

Berkowitz, D. \& Lee, J. (2004). Media relations in Korea: Cheong between journalists and public relations practitioners. Public Relations Review, 30, 431-437.

Cameron, G. T., Sallot, L. M. \& Curtin, P. A. (1997). Public relations and the production of news: A critical review and theoretical framework. Communication Yearbook 20. Newbury Park, California: Sage.

Chen, N. (1996). Public relations in China: The introduction and development of an occupational field. In: Culbertson, H. M. \& Chen, N. (eds.) International public relations: A comparative analysis. Mahwah, New Jersey: Lawrence Erlbaum Associates. 
Cobb, R. W. \& Elder, C. D. (1972). Participation in American politics: The dynamics of agendabuilding, Baltimore, Johns Hopkins University Press.

Curtin, P. A. (1999). Reevaluating public relations information subsidies: Market driven journalism and agenda-building theory and practice. Journal of Public Relations Research, $11,53-90$.

Curtin, P. A. \& Rhodenbaugh, E. (2001). Building the news media agenda on the environment: A comparison of public relations and journalistic sources. Public Relations Review, 27, 179-195.

Cutlip, S. M., Center, A. H. \& Broom, G. M. (2006). Effective public relations, Upper Saddle River, New York, Pearson Prentice Hall.

Entman, R. M. (1993). Framing: Toward a clarification of a fractured paradigm. Journal of Communication, 43, 51-58.

Gandy, O. H., Jr. (1982). Beyond agenda setting: Information subsidies and public policy Norwood, New Jersey, Ablex.

Goffman, E. (1974). Frame analysis: An essay on the organization of experience, Cambridge, Harvard University Press.

Hallahan, K. (1999). Seven models of framing: Implications for public relations. Journal of Public Relations Research, 11, 205-42.

Harrison, K. (2011). Strategic public relations: A practical guide to success, South Yarra, Victoria, Palgrave Macmillan Publishers Australia.

Huang, Y. H. (2000). The personal influence model and gao guanxi in Taiwan Chinese public relations. Public Relations Review, 26, 219-36.

Kopenhaver, L. L. (1985). Aligning values of practitioners and journalists. Public Relations Review, 11, 34-42.

Lang, G. E. \& Lang, K. (1981). Watergate: An exploration of the agenda-building process. Mass Communication Review Yearbook, 2, 447-469.

Lipschultz, J. H. (1991). A comparison of trial lawyer and news reporter attitudes about courthouse communication. Journalism Quarterly, 68, 750-763.

McCombs, M. (1992). Explorers and surveyors: Expanding strategies for agenda-setting research. Journalism Quarterly, 69, 813-824.

McCombs, M. (2005). A look at agenda-setting: past, present and future. Journalism Studies, 6, 543-557.

McCombs, M. \& Ghanem, S. (2001). The convergence of agenda setting and framing. In: Reese, S., Gandy, O. \& Grant, A. (eds.) Framing public life: perspectives on media and our understanding of the social world. Mahwah, New Jersey: Lawrence Erlbaum Associates.

McCombs, M. E. \& Shaw, D. L. (1972). The agenda-setting function of mass media. Public Opinion Quarterly, 36, 176-185.

McKinney, B. (2007). An investigation into the perceptions of public relations of Vietnamese business managers. Public Relations Quarterly, 52, 44-48. 
Newsom, D., Turk, J. V. \& Kruckeberg, D. (2000). This is PR: The realities of public relations Belmont, California, Wadsworth.

Nguyễn Thị Thanh Huyền (2010). Co-orientation study of professional relationship, public relations practitioners' roles, and news values between Vietnamese journalists and public relations practitioners ( $\mathrm{PhD}$ thesis). Korea: Sogan University.

Reese, S. D. (1997). Framing public life: A bridging model for media study. A synthesis keynote review presented at the inaugural conference of the Center for Mass Communications Research, College of Journalism and Mass Communication of the University of South Carolina. Columbia.

Roberts, M. \& McCombs, M. (1994). Agenda setting and political advertising: Origins of the news agenda. Political Communication, 11, 249-262.

Sriramesh, K., Kim, Y. \& Takasaki, M. (1999). Public relations in three Asian cultures: An analysis. Journal of Public Relations Research, 11, 271-292.

Sriramesh, K. \& Verčič, D. (2009). The global public relations handbook: Theory, research, and practice, New York, Routledge.

Stanton, R. C. (2009). Focus on Asian public relations management. In: Chia, J. \& Synnott, G. (eds.) An introduction to public relations: from theory to practice. Australia and New Zealand: Oxford University Press, 357-384.

Stanton, R. C. (2007). Media relations, Melbourne, Victoria, Oxford University Press.

Taylor, M. (2000). Toward a public relations approach to nation building. Journal of Public Relations Research, 12, 179-210.

Turk, J. V. (1985). Information subsidies and influence. Public Relations Review, 11, 10-25.

Van Leuven, J. K. (1996). Public relations in South East Asia from nation-building campaigns to regional interdependence. In: Culbertson, H. M. \& Chen, N. (eds.) International public relations: A comparative analysis. Mahwah, New Jersey: Lawrence Erlbaum Associates.

Van Thi Hong Loan (2014). The nature of public relations in Vietnam. Journal of Science Ho Chi Minh City Open University, 4(12) 2014, 54-66.

Watson, J. (2008). Media communication: An introduction to theory and process, Basingstoke, Palgrave Macmillan.

Weaver, D. \& Elliot, S. M. (1985). Who sets the agenda for the media? A study of local agendabuilding. Journalism Quarterly, 62, 87-94.

Williams, A. (2004). Examining agenda-setting and framing theories from a public relations perspective: Implications for professional practice and future research approaches. Paper presented at the Public Relations Division of the International Communication Association annual convention. New Orleans, LA.

Wu, M. Y., Taylor, M. \& Chen, M. J. (2001). Exploring societal and cultural influences on Taiwanese public relations. Public Relations Review, 27, 317-336.

Zoch, L. M. \& Molleda, J. (2006). Building a theoretical model of media relations using framing, information subsidies and agenda-building. In: Botan, C. H. \& Hazleton, V. (eds.) Public relations theory II. Mahwah, New Jersey: Lawrence Erlbaum Associates. 